\title{
Critique and medical education: towards liberating knowledge. Part II
}

\author{
Leonardo Viniegra-Velázquez* \\ Unidad de Investigación en Medicina Basada en Evidencias, Hospital Infantil de México Federico Gómez, Mexico City, Mexico
}

\begin{abstract}
The critique of medicine begins at unveiling and specifying its network of predominant logics, ideas and practices: logics of disjunction and reductionism; the health-disease binomial; the natural history of the disease; the medicalization of social life; the dehumanizing technologization of medical practice and reductionist suppressive medicine. It goes on to argue about its role as agents of domination of limitless profit interests and as an expression of the power of the health industry, justifying itself with the proposal of alternatives tending to overcome that network: transdisciplinarity and the concept of organism as hierarchical totality and interacting with its environment, with respect to disjunction and reductionism; the cultural history of the disease in relation to the health-disease binomial and the dehumanizing technologization; good living, the search for spiritual, intellectual, moral and coexistence growth as meaning of human life, as an alternative to the medicalization and antidote of degrading traits and stimulating medicine of the endogenous healing forces of the organism whose foundation of possibility and credibility is the placebo effect as an alternative to suppressive therapy for non-communicable chronic conditions, based on the pharmacological effect with unfailing side effects. It concludes that without an education based on critique, liberating knowledge would hardly accompany and guide the various social groups in the search for an inclusive,
\end{abstract} pluralistic, egalitarian, fair, solidary and caring of the planetary ecosystem world.

Key words: Reductionism. Medicalization. Suppressive medicine. Stimulating medicine. Placebo effect.

\section{La crítica y la educación médica: hacia un conocimiento liberador. Parte II}

\section{Resumen}

La crítica del quehacer médico como espacio educativo implicó caracterizar el entramado de lógicas, ideas y prácticas prevalentes: la disyunción y el reduccionismo; el binomio salud-enfermedad; la historia natural de la enfermedad; la medicalización de la vida social; la tecnologización deshumanizante de la práctica médica, y la medicina supresora reduçcionista. La crítica continúa discutiendo la contribución de ese entramado al control social como agente de la dominación de los intereses de lucro sin límites y como expresión del poder de la industria de la salud, justificándose con la argumentación de alternativas tendientes a superar ese entramado: la lógica transdisciplinaria y el concepto de organismo como totalidad jerarquizada e interactuante con su entorno respecto de la disyunción y el reduccionismo; la historia cultural de la enfermedad como alternativa a la historia natural de la enfermedad y al binomio salud-enfermedad; el bien vivir, la búsqueda de la superación espiritual, intelectual, moral y convivencial que confiere sentido profundo a la vida humana, como alternativa a la medicalización y antídoto de la tecnologización deshumanizante y los rasgos degradantes; la medicina estimulante de

\section{Correspondence:}

*Leonardo Viniegra-Velázquez

E-mail: leonardo.viniegra@gmail.com

2444-3409/○ 2018. Hospital Infantil de México Federico Gómez, published by Permanyer México SA de CV, all rights reserved.
Date of reception: 17-07-2018

Date of acceptance: 18-09-2018

DOI: 10.24875/BMHIME.M19000055
Available online: 14-01-2020 Bol Med Hosp Infant Mex. 2019;76:51-60 www.bmhim.com 
fuerzas curativas endógenas para afecciones crónicas no trasmisibles, cuyo fundamento de factibilidad y credibilidad radica en la omnipresencia del efecto placebo con respecto a la medicina supresora, basada en fármacos con efectos secundarios indefectibles. Sin una educación basada en la crítica, difícilmente el conocimiento liberador podrá acompañăr y orientar a médicos y otros profesionales a organizarse en la búsqueda, desde su ámbito, de un mundo inclusivo, igualitario, justo, solidario y cuidadoso del ecosistema planetario.

Palabras clave: Reduccionismo. Medicalización. Medicina supresora. Medicina estimulante. Efecto placebo.

\section{Introduction}

\section{Critique and medicine}

Critique of some medicine facets identifies and characterizes the prevailing logic, ideas, and practices in this vast area (orthodox and conventional knowledge, habits, and customs). That, as part of the medical curriculum as implicit assumptions and plain truths internalized by students, converts professionals into social reproducers of such knowledge that operate, as in other areas, as agents of the domination of limitless profit interests by consolidating, favoring or covering them up.

\section{The underlying logic}

The underlying logic-which escapes consciousness because it is not the object of reflection of those who act under their influence-operates as implicit rules of right thinking and acting. It governs and purifies the type of ideas and practices that predominate in this field, from the shadows, and for long periods.

- The logic of the disjunction, ${ }^{1}$ evident in the idea of the disease as an independent or autonomous object (nosological theory), in the separation between congenital and acquired or genetic and environmental and in the excision of once integrated endeavors that make up a division of medical and scientific work in progressive specialization that leads to the relentless emergence of specialties, subspecialties, disciplines and subdisciplines that become autonomous. The disjunction prevents the "victims" from capturing totalities and interdependencies among the endeavors where they are immersed, distancing them from an integrative vision that makes their world intelligible, insensitive to the crisis of civilization, which is permissive-by action or omission-with the domination of limitless profit interests.

- The ostensible reductionist logic ${ }^{1}$ pretends to explain and give an interpretation of each disease in itself ("natural history of the disease"), regardless of who suffers from it and, even less, of its circumstances and living conditions. Also, comparing a healthy organism with a "perfect machine" and a patient with a "damaged one" in which, by identifying its altered mechanisms, we could be able to act in order to restore its proper functioning. This mechanical approach is the root of the exclusionary specialization of the medical endeavor, a degrading feature that undermines it, where the specialist privileges a fragment or function of the organism and focuses his efforts on repairing it or returning it to the regular pattern, although such purpose may mean a damage to another fragment or function for the organism a whole or the patient's life. The machine, as a metaphor, is a poor idea of life, even of less complicated organisms, since it loses sight, among other vital qualities, that each organism is unique (not a machine with average performance). That the vital process is a perpetual interaction of the organism with its environment and changes incessantly generating novelties at every moment (development and maturation), that is set aside in experimental preparations: in those preparations, variations are caused to record a set of observations (not individualities), short-term unidifectional associations are sought in controlled situations within simplified and standardized environments (mechanistic causality). The idea of a mind machine and the expectations of physicians underlie many care failures attributable to patients who "dare to not behave in a mechanical manner": disobedience- indiscipline, fickleness, inconsistency, or rebellion. In biomedical research, physical-chemical reductionism underlies the type of approached problems, the hypotheses, the experiment design, the type of relevant events to be observed, and the interpretation of findings. The predominance of this type of research is due to its higher probabilities to be financed and of disseminating its results, which are-surprisingly-in line with the dominant interests in two senses: a necessary. consumerism of "cutting-edge technology" essential for an avant-garde endeavor and having access to high-impact journals, which contributes to this juicy business, and more importantly, its results are the quintessential input for technological innovations, spearheading the 
competitiveness of mega businesses and the achievement of high-profit rates. The profusion of innovations configures and reconfigures an increasingly fragmented, impersonal, and technology-dependent medical practice that is called dehumanizing technology, where both professionals and patients idealize technology 2 and underestimate the clinical skills. Thus, the specialist becomes a mere operator of "smart technologies" and a machine prescriber of "the best drugs" according to the fashion in turn.

The overwhelming predominance of mechanistic and physical-chemical reductionism in the life sciences is revealed by the widespread conviction that investigating the physical-chemical microcosm is truly scientific; the rest are weak imitations, illusions or fantasies. Also, this conviction has the belief that the ultimate explanation of the vital processes and diseases lies in that molecular microcosm, ignoring the natural order and confusing description with explanation. The exhaustive description of the vital motion in physical-chemical terms-characterizing infinity of compounds, reactions, sequences, networks, and mechanisms in order to reconstruct patterns, models, and functions-in addition to being an unattainable goal before an infinite, changing and cognitively inexhaustible microcosm, it cannot explain the characteristic biological order: the permanence, stability and perpetual change (growth, development, maturation and aging) of a whole of profound complexity, given by the processes of integration and regulation of an infinity of functions, behavioral complexity, cycles and rhythms that obey the organism forms of interaction with objects of its environment modulated by its age.

\section{Explicit ideas and prevailing practices}

As for the predominant ideas and practices in this field and at this time, which manifest themselves intertwined, the first thing to highlight is the following:

- The binomial health-disease that governs the organization, operation, and strategies of health institutions on a global level and tends to value human life and its difficulties by the presence or absence of disease. Although the idea of health according to the World Health Organization is the complete physical, mental and social well-being, its evident alienation to the human condition, and its disproportion and vagueness made the concept of "non-disease" to prevail, which obscured and supplanted the meaning of a decent, pleasant, stimulating or serene life. However, the institutions and the overwhelming advertising have turned the health preservation or its recovery into the vital imperative that progressively shapes the way of being and living of people. Such social pressure causes, on the one hand, a "pathological obsession" for health and, on the other, a disease phobia, which generates a growing market of compulsiveconsumers of "the good things to recover or preserve health", which supports the buoyant and robust industry and explains the undisputed and exclusive predominance of this binomial in the visualization of human life that obeys its compatibility with the dominant limitless profit interests.

- The medicalization of human life. In the described social environments, the population is increasingly dependent on health services and is introdueing "medical rationality" (warning and perpetual sưspicion of disease and relentless struggle) into their lifestyles as the center of their concerns and vital responsibilities: it is the medicalization of the way of life. ${ }^{3}$ Medicalization, as an expression of the predominance of the health-disease binomial, is not a necessary consequence of the assimilation of scientific truths into everyday life. However, a historical sifuation configured by industry (in all its variants) thathas as its raison d'être, far above any other consideration, obtaining high rates of profit by manipulating the market with incessant and intimidating advertising that inoculates helpless victims (including service providers) with high doses of deceptive fantasies, unsupported illusory securities, induced fears, created and alienating needs, or unfounded expectations. Progressively, the vicissitudes of daily life, once faced as minor vicissitudes, now become "health problems" that increase the consumer market and divert the attention of those seeking help fromethe social processes that underlie the growing and early presence of somatic and psychic (chronic) diseases: increasingly adverse conditions and circumstances for dignified, stimulating, productive, rewarding, serene and fraternal ways of life. In other words, medicalization operates as one of the most effective consciousness control mechanisms that self-absorbs people and makes them indifferent, insensitive or involuntary accomplices to degradation. Here; the harmony with the dominant interests is multiple: it strengthens them because medicalization is a condition for the prosperity of the industry, it favors them, by propitiating compulsive consumerism, and it conceals them, by controlling minds and bodies.

- The idea of social progress, as an incessant techinological development in atmospheres shapedz by 
degrading traits, propitiates the technology fetishism, ${ }^{2}$ the root of the dehumanizing technologization of current life and medical practice in particular, the most current face of degradation and the most covert form of consciousness and body control at the service of the domination of profit interests. Similarly, the idea that more significant research and technological development means higher health care progress is debatable, illusory and misleading, because researchers, prisoners of physical-chemical reductionism, subject to the health industry interests and immersed in medicalization, reduce their contributions to the input of technological innovations required by the selective funding of projects based on the industry interests (there are each time more commissioned projects), which determines the established research priorities, the type of problems that arise, the ways of investigating them and the technology used in their realization. In such situations, freedom of research is a lure, the critical and creative potential of this work fades, and the search for funding progressively supplants the search for knowledge. With few exceptions, the research on health problems (real or creations of medicalization) that promise high profitability due to the potential market of induced consumers is funded. Those that are not promising for businesses that afflict precarious majorities are left aside, whether they are the most pressing, prevalent, of high incidence, of more considerable morbidity or with available treatments, non-invasive or of more significant potential benefit. Hence the blame: "what science is this, that remains indifferent, complacent, acquiescent or accomplice to the dominance of limitless profit interests, that sink civilization and devastate the planet!".

\section{Some alternative logic, ideas, and practices}

After characterizing the relevance of the predominant logic, ideas, and practices and arguing the reasons for their predominance, we then recapitulate and update essays on various issues developed in the last two decades that involve alternative logic, ideas, and practices in an attempt to overcome the establishment.

- Transdisciplinary logic. As an alternative to mechanistic reductionism, transdisciplinary logic is implicit in the theory of the organism as a complex totality-the inherent complexity of life-that supposes systemic processes of integration and regulation that affect all levels of the vital organization: molecular, subcellular, cellular, tissue, and organic. They obey the anticipations of the situations of interaction with the meaningful objects of their environment towards the consummation of the essential vital activities: preservation of integrity and vitality, nourishment, reproduction ${ }_{\text {and }}$ coexistence with equals-cultural forms-in -the course of the different phases of ontogeny: growth, development, maturation, and aging. ${ }^{4}$

This holistic view of ontogeny inspired by the Gaja theory would mean for medicine a nosological decentralization that favors inclusive specialization (inver rse to excluding and disjunction) that relativizes its lablors in a broad context of interdependencies and weighs decisions and recommendations according to that wholeness. ${ }^{5}$ It would also favor humanistic mediêine because its referent is not the disease but patients in their circumstances. In the scientific field, such an approach would make it possible to transcend physical-chemical reductionism as the only scientific truth and bring a turning point in the type of problems that are posed, in the way they are dealt with and, above all, in the interpretation and evaluation of the findings. - The cultural history of the disease, ${ }^{6}$ an alternative to the idea of prevalent disease, is a holistic perspective of understanding (chronic) disease that reveals the current dogma illusion: the natural history of the disease. ${ }^{7}$ Because in the explanation of human condition, culture has been relegated and subordinated to nature. From dawn onwards, humans faced the inescapable presence of discomforts of some magnitude and persistence that implied physical or mental suffering, several limitations for carrying out tasks, various inconveniences for living with others, or premature death. Thus, the distinction arose between events that signified or announced discomfort orssuffering and those that were favorable or proper to an ordinary life: the former was considered, in essence, different from the latter and, therefore, as strangers to the organism that our ancestors learned to

a James Lovelock's Gaia theory, the result of his carefuf and lengthy research, puts forward unquestionable arguments to explain what life is and why it prospered on our planet "... except when life takes charge of their planet and occupies it extensively, the conditions necessary for its persistence- are not met. Planetary life must be able to regulate its climatesand chemical state. Partial periods, incomplete occupation, of occasional visits are not sufficient to overcome the inescapable forces that govern the chemistry and physics of a planet"- This passage interpreted within the discursive and conceptual framework of the ontogeny theory could be expressed: the most distinctive characteristic of life as a whole on a planetary scale is the anticipation of itself by creating and reproducing the conditions for its permanence and evolution. 
recognize, value, counteract, lessen or bear according to their myths, traditions, and possibilities. Historically, diverse cultures have shaped environments favorable to particular diseases, created ways of understanding, perceiving and recognizing them, acting upon them, coping with them, and dying. By virtue of culture-not nature-the "nosological landscape" has been transformed over time: eradication, reduction, persistence, reappearance or exacerbation, depending on the region, of infectious and deficiency diseases; vertiginous increase in the prevalence and precocity of chronic-degenerative diseases; incessant emergence of new infectious and occupational diseases; dreadful worsening of iatrogenic diseases, diversification and intensification of addictions or growing multiplicity of remaining "congenital errors of metabolism".

According to the cultural history of the disease, chronic diseases are not independent objects or alien to the organism, but rather "peculiar and differentiated variations of the ways of being of humans which, due to their unfavorable character, are the reason for sui generis actions by the culture of belonging, with the purpose of avoiding them, suppressing them, mitigating them or preventing their most harmful effects". From here another idea derives: "individuality that, by its biological and cultural heritage, by the multiplicity of environments of which has been a part and the incidents of the day to day, has reached a certain way of being that causes suffering, discomfort, inconvenience or limitations that require support, understanding, help and comforting actions". Under the intellectual and interpretative framework of the cultural history of the disease, physicians and patients could raise awareness of the "unhealthy and pathogenic" environments that underlie the "pandemic" of chronic diseases and their context: the unjust order that annihilates people's yearnings for freedom and justice; sweeps away the values of respectful, supportive, cooperative and fraternal coexistence (the empire of degrading traits), and devastates the world ecosystem. Such a perspective could contribute to a renaissance of humanism, by distancing itself from mechanistic reductionism and revaluing the role of the physician-patient relationship by weakening medicalization and the techno-fetishism that sustains it, by "humanizing" technology and promoting vital projects committed to the search for good living and a rethinking of the problem of health research and its priorities. As an expression of this renaissance, it would acquire priority in medical work to favor, in the chronically ill, the search for autonomy and dignity by appealing, among other alternatives, to existential exhortations, such as the following ${ }^{6}$ :

"Illness is a way of being that we cannot choose, or avoid; it is usually adverse to our desires, aspirations and innermost projects; we must understand it, sume it, overcome it and learn to live with it peacefully; only in this way illness will accompany us to be better, more dignified, understanding and supportive." - Good living. With respect to the idea of health absence of illness-whose preservation was installed as a vital imperative and is the foundation of the medicalization of life, a humanizing alternative inthis field is the concept of good living ${ }^{8}$ with a background in a tradition of the commitment of being a "respectable person" integrated by two components: the possession and use, with restraint, of the necessary and sufficient goods for a daily life with satisfaction and wellbeing, and the care and preservation of life- by acting with diligence, honesty, moderation and wisdom. These substantial ideas of an individualistic nature merit a rethinking based on the priority of other values and imperatives in these dark timess, a collective character in the search for a hospitabble world: altruistic vital projects that fight for dignifying human and worldly life (dignity is the primary victim of degradation and the basis of human progress) ${ }^{9}$ as a convergence center of initiatives arising in the various spaces of social work that, as multicentric forces, undertake from different fronts the search for genuine progress and the gradual building of a world favorable to spiritual overcoming (materialism, othe only recognizable face of progress in these times of obsession with consumption, is usually an obstâcle to progress), where health care as a vital polarizing obsession would acquire another physiognomy and a different meaning under other priorities. It is a propitious companion to forms of dignified, serene, fraternal and responsible life to take care of the world ecosystem.

- Suppressive Medicine (SuM) and Stimulant Medicine (StM). Referring to the critique of therapeutic practice-this transcends to the surface of events beyond specifying and correcting "malpractice" or preventing collateral damage-one of its most prominent features stands out concerning the ambition of the-actions of eliminating or destroying the foreign and autonomous object (the disease) through an ever-growing arsenal of anti-inflammatory, antihypertensive, anti-rheumatic, immunosuppressive, anti-allergic, antineoplastic, anxiolytic or antidepressant. It is SuM, where technological innovations (new drugs), 
a crystallization of physical-chemical reductionism, produce their effects by suppressing specific molecules or chemical reactions considered origin-cause of the disease. ${ }^{9}$ SuM is predominant in the West, despite its exorbitant costs, innumerable failures, and indefectible side effects to the extent of motivating the development of quaternary prevention, ${ }^{10,11}$ because it represents the most lucrative part of the "health industry" (in tune with the dominant interests). This industry, while imposing and promoting SuM under the slogan of "epitome of science," discredits and excludes (as "anti-scientific") other forms of treatment such as alternative medicines (AM).

In the ancestral AM, the disease is understood as a kind of systemic disharmony, and AM seeks to re-establish health by stimulating-not suppressing-endogenous healing forces, of whose existence the placebo effect is unequivocal evidence. From this, they are considered variants of StM. ${ }^{9}$ The AM, by using low-cost traditional technologies and favoring autonomy in patients, less dependence and vulnerability to medicalization, and a reluctance to consume medications represent an obstacle to the "big health industry" and the underlying reason for its disqualification and exclusion $^{b}$. Thus, the critique allowed to reveal contrasting characteristics of current therapeutics-which remained in the shadows or hidden in their apparent homogeneity: suppressor and stimulant, a characterization not exempted from simplification and schematism. To specify the differences between SuM and StM, the most persuasive arguments derive from contrasting the pharmacological effect (PhE) of SuM and the placebo effect (PE) that supports the possibility of StM.

The PhE originates in the physical-chemical microcosm by modifying reactions and molecules to which a significant causality of the condition is attributed. This causal idea, together with that of active treatment with chemicals (drugs), exemplifies the reductionist thinking that a complex system can only be explained by reducing it to its fundamental (simple) parts..$^{12}$ The target of a drug, within an immeasurable integrated and hierarchical complexity from the macro-psychosocial to the microphysical-chemical, is an infinitesimal element that forms part and is configured by a sequence of reactions. At the same time, it is a link of chains integrated into networks with intricate mechanisms, which articulate

b It is clarified that the stimulating character of the AM has no guarantee that they will invariably achieve their purposes nor that they will be immune to charlatanism and fraud, as particular situations of our time. and couple within metabolic and functional paths of organic regulation and integration, preserving the syystemic, cyclic and rhythmic character of the vital process of an organism in constant interaction with its environment. The introduction of a foreign and reactive substance in such a vital concert, attempting a $\mathrm{PhE}$, causes a "discordance" with the regulatory and integrative flow, whose direction is from the macro to the micro, manifests in the need to repeat the drug indefinitely (chronic affection), in indefectible secondary reactions, infrequent reactivations or exacerbations that force modifying the treatments with new side effects, to add more suppressors closing the vicious circle, which for industry is a "virtuous" one.

The stimulating nature of specific therapeutic strategies, which may seem fanciful, illusory or meaningress to orthodox believers, has an unequivocal empirical basis in the omnipresence of PE in curative situations of all kinds (this includes, of course, drug-based treatments). ${ }^{c}$ PE refers to the symptoms, signs or discomfort improvement, or the favorable modification of patient's altered laboratory indicators not attributable fo a deliberate therapeutic intervention, which is the result of a systemic mobilization of the organism induced by autosuggestion, derived from the confidence of fimprovement deposited in particular objects that are significant in the healing environment: an affectionate doctor, a red pill, a powerful injection, a veneratedeimage or a place of worship, almost always due to previous favorable experiences. ${ }^{13} \mathrm{PE}$, which reveals the existence of endogenous healing forces ${ }^{d}$, whose mobilization from the macro (systemic) to the micro (physical-chemical) anticipates what is expected is

c A crass error of scientific research that only looks at facts, not ideas, is to confuse PE with "placebo stuff." The beliefthat comparing a drug with an inert substance allows to separate the PhE from the PE loses sight of the fact that in any "curative situation" PE may be present and that, in many cases, the benefits attributed to a drug are due more to PE-incited in the therapeutic process-than to the pharmacological one.oFurthermore, the so-called nocebo effect-inverse to PE-which alludes to the worsening of symptoms, signs or discomfort of the patient due to the suggestion/expectation of adverse effects of a therapy due to previous experiences, does not correspond to a secondary effect attributable to a drug, so it is possibje to speculate about its participation-as added to the undesirable effects-in unfortunate or counterproductive results of certain forms of suppressive therapy (chemotherapy).

d This would explain why PhE-the reverse of PE-can exacerbate discomfort (counterproductive consequences) by weakening or opposing endogenous healing forces, or decaying by "contending" with such forces which requires increasing the dose (increasing the risk of new or more severe side effects) or switching to "higher potency" drugs. 
present in a great diversity of healing situations as long as the search for relief is intense. This omnipresence of $\mathrm{PE}$ resulting from the mobilization of endogenous healing forces (of astonishing selectivity), whose direction from the macro-psychosocial to the microphysical-chemical, justifies recognizing it and posing it as an unrecognized "physiological variant" that accompanies the incessant regulatory and integrative flows of the organism - a variant that is updated under peculiar circumstances-induced by the confidence of being alleviated and conducted, with exquisite selectivity, to the location, intensity and characteristics of the discomfort, which is ahead of expectations and manifests itself in the improvement of a multiplicity of disorders (the interest in investigating the PE has been declining; hence the references are not recent). ${ }^{14-20}$ At first glance, it would appear that $\mathrm{PE}$ is a faithful reproduction of $\mathrm{PhE}$ or vice versa, causing analogous physical-chemical changes. However, there is a radical difference: PE obeys a pattern of systemic mobilization that is psychosocially born and follows paths through different descending levels of complexity causing relatively stable "rearrangements" (which explain the absence of side effects) between systemic cycles and rhythms, behaviors, functional patterns, metabolic pathways, mechanisms, networks and chains of reactions that anticipate what is expected, producing a discomfort improvement with astonishing specificity. Raising awareness of the universality of PE that confers credibility to the stimulating character of some AM can open minds to new spaces for reflection, understanding and, above all, for examination of the most influential social task in the life of present societies that derive inconvenience, and even in the need to incorporate the StM as a promising alternative for chronic affections. For a broader and more detailed treatment, the reader is referred, for reasons of space, to other sources. ${ }^{9,21}$

\section{Epilogue}

Critique understood as the logic of methodical thought of the process of cognition that questions everything, doubts the "proven and definitive," goes to the root of what is considered "natural and evident" and proposes ways of thinking and acting that seek to overcome what is established concerning the cognitive objects. Furthermore, it underlies the construction of this essay that, from the beginning, proceeded to retake the diagnosis of the current historical situation ${ }^{3}$ and of the social conditions and circumstances that made it possible, which are synthesized to recapitulate, in the form of assumptions, accompanied by an explanatory thesis, which constituted the interpretative, evaluative and argumentative framework of this work on the critiquie of medical education:

- The two assumptions are linked: first, the world devastated by an omnipresent degradation shows the exhaustion and ruin of a civilization based on limitless profit, which turns the most sublime and vile of the human condition into merchandise, and the worst atrocities and planetary devastation into profitable products, compromising the viability of our species as never before. Second, civilization collapse, as the point of arrival to a process of gradual decadence, cannot be understood without the insensitivity of societies with the highest historical level of schooling and the scarce or insufficient resistance of the diverse social organizations (throughout the planet) which react to adversity in a dispersed, detached or confused manner, or remain indifferent, permissive or complicit to degradation.

- The thesis to explain why the dominance of profit interests has swept away without finding significanfobstacles to its destructive power needs to recognize the enormous effectiveness of the control of consciousness and bodies by the system of domination that operates through three "non-violent" apparatuses?

- The media. The traditional and cybernetic mass media; and the entertainment media (especially sports), whose target is the manipulation of affections by inciting pleasures, phobias, convictions hatreds, sympathies, conformism, fatalism or fearsand by persuading, misinforming or "fabricating realities"; by concealing and making this degradation invisible; by spying, confusing, deceiving or aliehnating; by venting emotions towards catharsis and elvasion by "depressurizing" indignation, discontent, protest or rebellion against an unequal, unjust, excluding and dehumanized system that resorts to the worst atrocities (dispossession, wars of all kinds, téfror, elimination) in order to maintain its domination.

- The school-level. At all levels, via passive (prevalent) education that perpetuates degrading traits, such as individualism, passivity (in the face of power abuses of all kinds), competitiveness, consumerism (real or imaginary), exclusionary specialization and vulnerability to manipulation, which hare the sine qua non of domination, and reproduces the ideas and practices predominant in the multiplicity of social spaces.

- The labor level. In all its variants, in virtue of the fact that each space is governed by ideas and 
practices whose predominance obeys its harmony, direct or indirect, with the dominant interests of limitless profit that, when escaping the conscience ("they are the same reality") or considering the indisputable incarnation of progress, operate, perhaps, as the most effective-and less-recognized-"device" of social control.

Under this interpretative and evaluative framework, we differentiated between two objects, in the critique of medical education, education, and labor, in order to capture their particularities in the ways of controlling consciousness and bodies. The first, through the perpetuation of degrading traits and the social reproduction of prevalent ideas and practices in each workspace; the second, through the intrusion of the uses and customs (predominant ideas and practices) that make up each specialized and exclusive space where degrading traits prevail. Therefore, the separate presentation of the particularities of each field, trying not to dissociate them.

\section{Education}

Concerning the critique of passive education (also prevalent in medicine), in order to deepen it, we required, as a minimum, glimpses of contrasting alternative ideas and practices as a condition for characterizing it. In other words, this critique needed to have at least sketches of a theory of participatory education, which was achieved by revealing, by contrast, relevant aspects, and details that had gone unnoticed or remained silent, and vice versa.

The core of passive education is represented by the idea of knowledge comparable to rote, accumulative and ephemeral learning of heteronomous information, devoid of meaning, and by the implicit pedagogy centered on facilitating the consumption and dogmatic assimilation of established truths that, in turn, favor a reading of unreflective and uncritical comprehension as a form of prominent relation of the students with the contents of the curriculum. This fact explains their decisive contribution-involuntary-to the persistence of the degrading traits that permeate social atmospheres since, far from criticizing and discouraging them, it propitiates their perpetuation.

The theory of participatory education, an alternative to passive education resulting from its critique, maintains that knowledge is the elaboration and re-elaboration of the learners themselves, with the indispensable mediation of critique, which constructs and reconstructs their versions of themselves and their context. Implicit pedagogy is condensed into spreading enthusiasm for understanding who we are and where we are, and seeking environments conducive to critique and the elaboration of knowledge. The act of studying responds to an enthusiastic search to understand, through critique, issues with meaning for the experience of life which leads to raise awareness, judge and propose, with infinity of variants and nuances, regarding what is right or wrong what is exciting or dull, what is enlightening or confusing, what is strong or weak, or external coincidences, discrepancies or proposals to overcome. The participatory path presupposes progressively penetrating and liberating knowledge, which is the primary antidote to degrading traits and an imperious necessity in these times-especially if one aspires to revêrse degradation, which is a condition for leaving a hospitable world to the generations to come-which implies a keen awareness of the human world, and in the fong run, a power of collective self-management capable of forming multicentric and convergent social forces whose distant but not imperceptible horizon are participative, inclusive, egalitarian, just, supportive and Earing societies of the planetary ecosystem, in perenial search of the spiritual, intellectual, moral and convivial overcoming of the human condition.

\section{Medicine}

For the propositional critique of the predominant ideas and practices of medical labor that began decades ago, ${ }^{22}$ we recapitulate the different topicspdeveloped and group them according to the prominent aspects of the critique.

- Unveil the organizing logic of thought and action: disjunction, mechanistic, and physical-chemicaß reductionism. To specify predominant ideas and practices in this field: exclusionary specialization as the current form of division of labor; the health-disease opposition and natural history of disease that govern the institutional health care strategies and, at the level of experience, by virtue of the prevailing idea of progress, the medicalization of human life that polarizes the ways of life of both professionals and patients and the dehumanizing technologization that distorts the essence of medical work.

- To propose and argue alternatives tending to overcome the establishment regarding objects of cognition: The concept of the organism, based on the recognition of the biological and cultural order under a trannsdisciplinary perspective that integrates living beings, including humans, as an alternative to disjunction, 
physical-chemical reductionism, and exclusionary specialization.

The cultural history of the disease, as a transdisciplinary view where diseases (particularly chronic ones) are variants of people's ways of being; as an alternative that highlights the limitations of the natural history and the idea of disease.

The concept of good living that emphasizes the recovery of the meaning of life that has occupied the great philosophies: the spiritual, intellectual, moral and convivial overcoming of the human in its aspiration to have worthy, serene, cooperative, fraternal, solidary and planetary ecosystem liable forms of life, which implies the undertaking of collective and altruistic vital projects committed to the dignification of life in all its manifestations. This concept is the alternative to health and medicalization that polarizes the vital energy in the care of one's health and the fight against disease and diverts attention from the degradation that is the backdrop of uneasiness and rampant afflictions; it also represents a vital path divergent from that of the empire of degrading traits. ${ }^{e}$

By deepening the critique of the therapeutic extent of the various western and eastern medical strategies, we clarified a qualitative difference between the mechanisms of action of the remedies, which, when contrasted, made it possible to clarify, on the one hand, the suppressive nature-of molecules and chemical reactions-of the drugs used in the treatment of diseases, especially chronic no communicable diseases, which are inevitably accompanied by side effects. On the other hand, the stimulating character, exemplified by the omnipresent placebo effect in every curative situation and in the ancestral alternative medicines which, in spite of being the object of discredit, disqualification or exclusion for obstructing the "great business of health", entails potentialities worthy of investigation and exploitation for the benefit of the mourners.

This essay underlines that the critique of medical education implies the obligatory questioning of both

e It is worth highlighting the critical role played by contrasts (between predominant and alternative or between oppositions and divergences) in the construction of this essay, their part in the possibilities of critique, the scope and strength of the arguments and, consequently, their function as irreplaceable material for deepening critique in the search for environments favorable to exercising it and elaborating progressively penetrating knowledge, all of this as part of the process of training other types of physicians committed to a better world. Nothing could be more distant from senseless learning, based on the consumption and accumulation of established truths as heteronomous, fragmentary, unconnected, dogmatically assimilated information, characteristic of passive education. orthodox and conventional knowledge of what is educational and of medical practice. The profound and creative critique as the logic of methodical thought was the guiding wire of the construction of this work. Thus, the first is related to its profound character: the attempt to unravel the web of logic, ideas, and practices prevailing in each dimension, and unveil their way of operating as "agents of domination" of limitless profit interests, which have collapsed civilization and devastated the planetary êcosystem. The second has to do with the creative aspect: to develop alternatives tending to overcome what is taken for granted concerning the objects of knowledge.

As a synthesis of this work, it is necessary to complement the epigraph of the first part: "Really fecund teaching begins when it "spreads enthusiasm" for understanding who we are and where we are"; continuing: ".and proceeds at the moment of procuring more propitious environments for deep and creative critique, and for the elaboration of a penetrating and liberating knowledge".

Without an epistemological shift from prevailing education to participatory education, orienting the efforts of the protagonists towards a valid promotion andexercise of critique in its profound and creative connotation, it will be very difficult for penetrating and liberating knowledge to emerge and accompany today's soçieties-societies dragged to degradation and condemned to inhabit an inhospitable and devastated world to fulfil the supreme and indeclinable duty transmitted from generation to generation (which has become blurred in these dark times where degrading attributes reign, to the extreme of indifference and insensitivity towards such responsibility): the legacy of a world hospitable to future generations, which necessarily comes through the preservation and care of the ecosystem.

Although everyone has or should have their version of the events that mark our time, I would like to make it clear that by posing the current situation as the exhaustion and ruin of civilization, the purpose is neither to alarm nor to exaggerate, but to raise awareness and understanding of a somber historical moment that concerns everyone. An unprecedented moment due to spiritual, intellectual, moral and convivial degradation; by the annulment of the yearnings for freedom, equality, jusstice and self-determination of peoples; by the withdrawal and "reclusion" of the values proper to respectful, fraternal and supportive social relations; by the unstoppable planetary devastation; by the profitability of ethnocide and ecocide; by the absolute priority of good business over life (in its diverse manifestations) which causes the absolute pollution of the air, the seas, the rivers, the lakes, the soils, the plants, the animals, our food andzour 
bodies; by the annihilation of "redundant" and unsubmissive populations by means of wars (of all kinds) and terror; by the forced migration of millions by violence, plundering or poverty into "nothingness"; by the decimated biodiversity by human causes: the planetary devastation with almost all the existing wild species still threatened, at risk, endangered, on the way or in imminent extinction; by the already irreversible climate collapse ${ }^{23}$ that represents the impossibility of future opportunities for a dignified life for the majority of the human population ${ }^{24}$ and of favorable conditions for a robust biodiversity-Gaia's vital force-which deny, minimize or hide the extractive mega-companies and continue with their very profitable destructive and polluting actions.

We conclude with a paraphrase of the thought of Boaventura de Sousa Santos that alludes to another variant of the control of consciousness and bodies by the system of domination that helps its effectiveness: "In the world we live in, perversities are transformed, by their recurrence, into normality."

\section{Conflicts of interest}

The authors declare that they have no conflicts of interest.

\section{Funding}

None.

\section{References}

1. Morin E. El pensamiento subyacente. El método IV. Las ideas. Madrid: Cátedra;1998. 222-33.
2. Viniegra-Velázquez L. El fetichismo de la tecnología. Rev Invest Clin. 2000;52:569-80

3. Viniegra-Velázquez L. El bien vivir:¿cuidado de la salud o proyecto vital? Parte I. Bol Med Hosp Infant Mex. 2016;73:139-46.

4. Viniegra-Velázquez L. Anticipación y ontogenia. Penetrando el proceso vital: más allá de la adaptación, el azar y la selección natural. Teqría de la interiorización del entorno y la anticipación. Mexico: Ed. del Autor; 2012. 341-64.

5. Lovelock J. Las edades de Gaia. Una biografía de nuestro planeta vivo. Barcelona: Tusquets; 2000. 54-55.

6. Viniegra-Velázquez L. La historia cultural de la enfermedad. Rev invest Clin. 2008;60:527-44.

7. Leavell HR, Clark EG. Preventive medicine for the doctor in his community. An epidemiologic approach. New York: McGraw Hill; 1953.

8. Viniegra-Velázquez L. El bien vivir: ¿cuidado de la salud o proyectó vital? Parte II. Bol Med Hosp Infant Mex. 2016;73:283-90.

9. Viniegra-Velázquez L. Medicina supresora y medicina estimulantes una mirada penetrante de la práctica médica. Bol Med Hosp InfanfMex. 2018;75:267-278.

10. Martínez González C, Riaño Galán I, Sánchez Jacob M. Prevención cuaternaria. La contención como imperativo ético. An Pediatr (Barc). 2014:81:396.e1-e8.

11. Gérvas J, Pérez Fernández M. Uso y abuso del poder médico para definir enfermedad y factor de riesgo, en relación con la prevenció $\mathrm{P} c u a-$ ternaria en España. Gac Sanit. 2006;20:127-34.

12. Honderich T, editor. Reductionism. The Oxford Companion of Philosophy. New York: Oxford University Press; 2005. p.793-5.

13. Viniegra Velázquez L. El efecto placebo. Su dimensión teórica \&y sus implicaciones prácticas. Ciencia. 1987;38:131-46.

14. De Maria A, Craven DE, Heffernan JJ, Mclntosh TK, Grindlinger GA, McCabe WR. Naloxone versus placebo in treatment of septic shock. Lancet. 1985;325:1363-5.

15. Beecher HK. Pain in men wounded in battle. Ann Surg. 1946;123:96-104.

16. Beecher HK. Measurement of subjective responses. Quantitative effects of drugs. New York: Oxford University Press; 1959.

17. Porter JM, Culter BS, Lee BY, Reich T, Reichle FA, Scogin JT,-ett al. Pentoxifylline efficacy in the treatment of intermittent claudication multicenter controlled double blind trial with objective assessment of chronic occlusive arterial disease patients. Am Heart J. 1982;104:66-74.

18. Morison RA, Woodmansey A, Young AJ. Placebo responses in arthritis trial. Ann Rheum Dis. 1961;20:179-84.

19. Amsterdam EA, Wolfson S, Gorlin R. New aspects of placebo response in angina pectoris. Am J Cardiol. 1969;20:249-54.

20. Molling PA, Lockner AW, Sauls RJ, Eisenberg L. Committed delinquent boys: the impact of perphenazine and of placebo. Arch Gen Psychiatry. 1962;7:70-4.

21. Goldberg B, compilador. Medicina alternativa. La guía definitiva. Gâlifornia: Future Med Publish Inc; 1999. 37-48.

22. Viniegra-Velázquez L. ¿Qué significa la resolución de un problemaclínico? Rev Invest Clin. 1981;33:151-9.

23. Lovelock J. La venganza de la tierra. La teoría Gaia y el futuro'de la humanidad. Barcelona: Planeta; 2007.

24. Lovelock J. La tierra se agota. El último aviso para salvar nuestro planeta. Barcelona: Planeta; 2011. 